\title{
The Effect of a Weight-Loss Diet in Women Doing Reformer Pilates: A 12-Week Evaluation
}

\section{Aletli Pilates Yapan Kadınlara Uygulanan Zayıflama Diyetinin Etkisi: 12 Haftalık Değerlendirme}

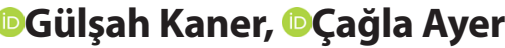

İzmir Katip Çelebi University, Faculty of Health Sciences, Department of Nutrition and Dietetics, İzmir, Turkey

\begin{abstract}
Aim: This study aims to define the effect of a weight-loss diet on body composition in women doing reformer pilates for 12 weeks. It compares dietary habits in subject groups with and without a weight-loss diet and macro and micronutrient intakes at the beginning and end of the study.
\end{abstract}

Material and Method: A total of 49 women ( $\geq 18$ age, $n=49$ ) were randomly allocated to either a control (CG: reformer pilates; $\mathrm{n}=23$ ) or a study (SG: reformer pilates+weight-loss diet; $n=26$ ) group. In both groups, subjects did pilates for 45 minutes a day three times a week for a total of 12 weeks. Their body weight $(\mathrm{kg})$, waist circumference $(\mathrm{cm})$, hip circumference $(\mathrm{cm})$, neck circumference $(\mathrm{cm})$, mid-upper arm circumference $(\mathrm{cm})$, body composition, waist/height ratio, and body mass index $\left(\mathrm{BMl} ; \mathrm{kg} / \mathrm{m}^{2}\right)$ were evaluated at the beginning and the third month of the study. Dietary habits of all subjects were questioned, their 24-hour retrospective food consumption was taken, and their physical activity levels were evaluated through the International Physical Activity Questionnaire (Short Form).

Results: The use of vitamin and mineral supplements in SG was lower than CG $(p=0.003)$. The twelve-week evaluation showed a significantly higher increase in dietary protein and calcium levels in SG than CG $(p<0.05)$. In SG, a significantly higher decrease was determined in body weight, BMI, waist circumference, hip circumference, and waist/height ratio, and a higher increase in Basal Metabolic Rate, body muscle, and body water, compared to CG $(p<0.05)$.

Conclusion: Pilates combined with a weight-loss diet has more positive effects on body composition than pilates alone. Providing dietary training and counseling for women who practice reformer pilates will increase the health benefits of exercise.

Keywords: Pilates-based exercises, weight loss, diet, women, body composition
Öz

Amaç: Bu araştırmada 12 haftalık sürede kadınlarda aletli pilatesin vücut kompozisyonuna tek başına veya zayıflama diyeti ile birlikte etkisinin karşılaştırılması amaçlanmıştır. Çalışmanın diğer amacı ise zayıflama diyeti yapan ve yapmayan grupların beslenme alışkanlıkları ve çalışmanın başlangıcı ve sonundaki makro ve mikro besin ögesi alımlarını karşılaştırmaktır.

Gereç ve Yöntem: Kadınlar ( $\geq 18$ yaş, $n=49$ ), kontrol (CG: Reformer pilates, $n=23$ ) ya da çalışma (SG: Reformer pilates+Zayıflama diyeti, $\mathrm{n}=23$ ) grubu olarak rastgele iki gruba ayrılmıştır. Katıımcılar, 12 hafta boyunca günde 45 dakika olmak üzere haftada üç kez pilates yapmıştır. Vücut ağırlığı $(\mathrm{kg})$, bel çevresi $(\mathrm{cm})$, kalça çevresi $(\mathrm{cm})$, boyun çevresi (cm), üst orta kol çevresi (cm), vücut kompozisyonu, bel/boy oranı ve beden kütle indeksi $\left(B K i ; \mathrm{kg} / \mathrm{m}^{2}\right)$ çalışmanın başlangıcında ve üçüncü ayda değerlendirilmiştir. Tüm katılımcıların beslenme alışkanlıkları ve 24 saatlik geriye yönelik besin tüketim kayıtları sorgulanmış ve fiziksel aktivite düzeyleri Uluslararası Fiziksel Aktivite Anketi (Kısa Form) (IPAQ) kullanılarak değerlendirilmiştir.

Bulgular: Çalışma grubunda vitamin ve mineral desteği kullanımının kontrol grubundan daha düşük olduğu saptanmıştır $(p=0,003)$. On iki haftalık değerlendirme sonucunda, SG'de CG'ye göre diyetle alınan protein ve kalsiyum düzeyinin anlamlı olarak daha fazla arttığı belirlenmiştir ( $p<0,05)$. SG'de, CG'ye göre vücut ağırlığı, BKI, bel çevresi, kalça çevresi, bel/boy oranının anlamlı olarak daha fazla azaldığı; bazal metabolizma hızı, vücut kas oranının ve vücut su oranının daha fazla arttığı gözlenmiş̧ir $(p<0,05)$.

Sonuç: Pilates ile birlikte zayıflama diyetinin, tek başına pilates uygulamasına göre vücut kompozisyonu üzerine daha fazla olumlu etkisinin olduğu belirlenmiştir. Aletli pilates yapan kadınlara beslenme eğitimi ve danışmanlığı verilerek uygulanan egzersizden sağlanacak sağlık yararlarının artırılabileceği düşünülmektedir.

Anahtar Kelimeler: Pilates, aletli pilates, beslenme, kadın, vücut kompozisyonu

Corresponding (illetişim): Gülşah Kaner, İzmir Katip Çelebi University, Faculty of Health Sciences, Department of Nutrition and Dietetics, İzmir, Turkey

E-mail (E-posta): kanergulsah@gmail.com

Received (Geliş Tarihi): 05.10.2021Ａccepted (Kabul Tarihi): 20.10.2021 


\section{INTRODUCTION}

Pilates is a specific exercise program developed by Joseph Pilates (1880-1967) after World War I as a comprehensive method of muscle stretching and strengthening to build a robust body under the philosophy of mind control over the body. Initially adopted only by athletes and dancers, pilates has become popular in general sports activities and rehabilitation programs in recent years. ${ }^{[1]}$ In the twentieth century, it became widely known among women in particular. Women generally prefer reformer pilates exercises for aesthetic purposes such as losing weight, slimming, staying in shape, strengthening muscles, getting rid of muscle pain, and gaining flexibility. ${ }^{[2]}$

The literature does not suggest any consensus on whether physical activity is effective in ensuring total body weight loss and improving body composition. Typically, brisk walking or running is recommended for improving healthrelated variables. ${ }^{[3]}$ Exercises, such as pilates, benefitting the physiological, psychological, and motor functions of the body are also promoted for improving aerobic fitness, muscle mass, and body composition. ${ }^{[1,3]}$ Reformer Pilates is the practice of regular pilates exercises on a system consisting of a platform, bars, straps, and resistance springs. ${ }^{[4]}$ Such exercises not only make our body stronger and more flexible but also fix bad posture, teach us how to breathe correctly, and enable us to move smoothly at an ideal pace. A reformer can provide many benefits such as increasing the balance control of the body, improving joint mobility, and giving strength and flexibility to the muscles, thus lengthening them. ${ }^{[5-7]}$

Despite the growing popularity of pilates, there are a limited number of studies conducted on its effects on body composition, and the results are controversial. ${ }^{[1,2]}$ These studies recommend the use of devices such as bone mineral densitometry (DEXA) to precisely determine body composition. Lack of rigorous experimental designs with reliable and accurate results, unavailability of certified pilates instructors, and inability to control individual diet plans are the most critical limitations of not clarifying the effects of pilates on body composition. ${ }^{[1]} \mathrm{A}$ weight-loss diet alone or an exercise program combined with such diet is much more effective in creating changes in body composition than exercise alone. It is known that following a weight-loss diet along with an exercise program for a year affects body composition more positively than diet alone. ${ }^{[8]}$ In addition to all these, studies evaluating the dietary status of women who exercise are insufficient. ${ }^{[9]}$ In light of this, we hypothesized that the combination of reformer pilates and weight loss diet can more positively affect body composition than reformer pilates alone.

\section{MATERIAL AND METHOD}

\section{Experimental Approach to the Problem}

We conducted a randomized controlled clinical trial evaluating the effects of a 12-week weight loss diet intervention on body composition, muscle strength, and physical performance of reformer pilates women. This study took place from September to December 2020. All subjects were informed about the benefits and risks of the investigation and signed an informed consent form before the beginning of the study, which was approved by the Ethics Committee of Izmir Kâtip Çelebi University (Decision No: 629) and in line with the Declaration of Helsinki, good clinical practices, and applicable laws and regulations. The trial also registered at ClinicalTrials. gov under the process NCT04880525.

\section{Subjects}

Female subjects who were 18 years old and above, did not regularly practice pilates, and were physically independent to perform basic daily activities were included in the study. From a total of 50 candidates who were initially contacted and screened, 49 agreed to participate in the study. A flow diagram of the subjects is presented in Figure 1.

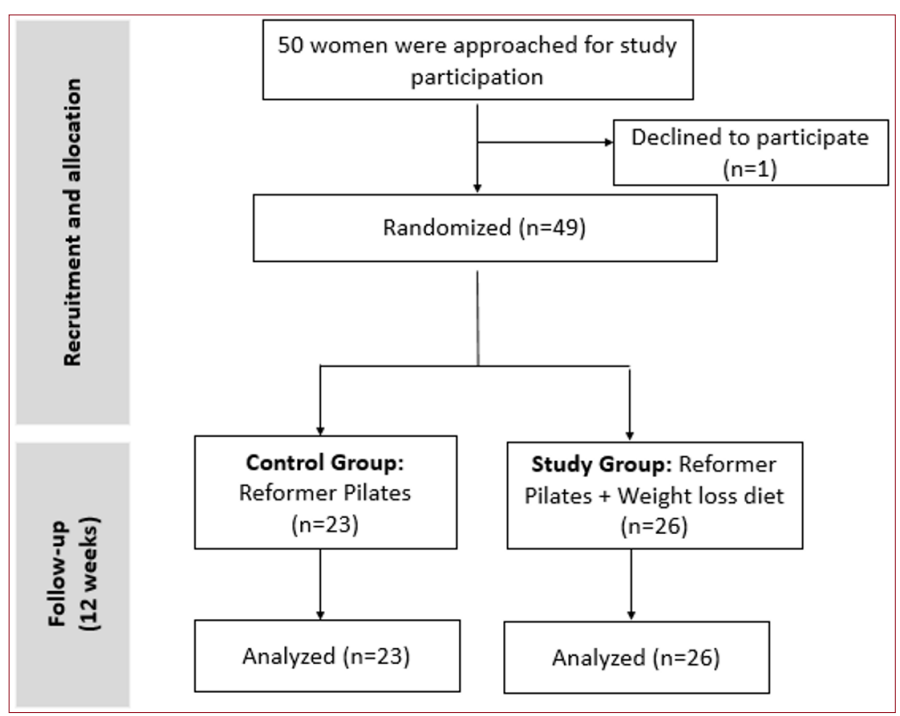

Figure 1. Research flow plan

Sample Size Calculation: Power analysis based on body fat percentages in a similar study ${ }^{[10]}$ on pilates showed that it was optimum to work with a minimum of 28 and a maximum of 69 subjects at 0.40 effect size, $95 \%$ power, and 5\% type- 1 error. As such, 49 subjects were included in the study who started doing reformer Pilates in the gym.

Randomization: The subjects were randomly allocated to either Study Group (SG, $n=26$ ) or Control Group (CG, $n=23$ ), in a 1:1 ratio, using a computer-generated random-numbers table. Women and investigators were blinded to group assignment. Allocations were performed in sealed, opaque, and consecutively numbered envelopes stored locked. Then, they were opened by an independent administrator who was not involved in the baseline evaluation, outcome assessment, or intervention procedures.

Procedure: Subjects allocated to the SG and CG received 3 sessions of pilates exercises (45 minutes per session) every week for a total of 12 weeks. The intervention was always 
performed by a well-trained instructor in the same local exercise center. A pilates training program was designed to improve muscle strength, resistance, and flexibility, and exercise difficulty was set to the basic-intermediate level (10 repetitions per exercise). Exercise intensity was gradually increased. Each session was divided into 3 periods: warmup (10 minutes), main pilates training activity (25 minutes), and cool-down (10 minutes). During the previous week, subjects were familiarized with the correct execution of the movements, the powerhouse, and the principles of the pilates method. Exercises targeted the lower body, trunk, and upper body areas, both in an isolated manner and through comprehensive routines that involved all areas at once. In weeks 1 and 2, exercises were performed in the sitting and standing position respectively. The rest of the intervention (weeks 3-12) also involved floor exercises. Subjects needed to attend the $80 \%$ of the training sessions at minimum to be included in the analysis. The participants were monitored in case of any possible complications, such as fatigue, dizziness, headache, feeling light-headed, shortness of breath, decreased reflexes, numbness in hands or feet, any sort of pain, and cold sweating.

Dietary Intervention: Women in the SG adopted a personalized weight loss diet in addition to the pilates exercise. These diet plans were customized to provide $45-60 \%$ of the energy from carbohydrates, $10-20 \%$ from protein, and $20-35 \%$ from fat, in line with Turkey Dietary Guidelines. No dietary or nutritional intervention was applied to the individuals in the CG. The status of women in the CG on any diet was often questioned.

Survey Form: The study plan consisted of two stages. In the former, a face-to-face interview method was used to question subjects about their socio-demographic characteristics, dietary habits, physical activity levels, food consumption records, and anthropometric measurements. In the latter, the subjects were divided into two groups as control and the study group. After the 12-week study, anthropometric measurements and food consumption records of the individuals were taken.

\section{Determination of Socio-Demographic Characteristics and Physical Activity Levels}

The subjects were questioned about their age, physical activity level, marital status, educational background, profession, and presence of a disease diagnosed by a physician. Their physical activity levels were inquired by means of the International Physical Activity Questionnaire (Short Form) (IPAQ-SF). This form consisted of seven questions and provided information about the time spent sitting, walking, moderate and vigorous activities. ${ }^{[11]}$ The total score included the duration (minutes) and frequency (days) of the activities performed. Physical activity levels were classified as physically inactive $(<600 \mathrm{MET}$ -min/week), low physical activity (600-3000 MET -min/week), and adequate physical activity (with health benefits) $(>3000$ MET -min/week). ${ }^{[11]}$

\section{Evaluation of Dietary Habits and Dietary Status}

In this section, general dietary habits of the subjects were evaluated, such as the number of main meals and snacks they consumed, if they skipped main meals and snacks, the reasons for skipping meals, and the food they consumed as snacks.

To determine the dietary status of each subject, their 24-hour food consumption records were taken retrospectively and the portion contents and grams were evaluated. After defining the amount of food consumed each day, their daily energy, macro, and micronutrient intake was questioned through the Nutrition Information Systems Package Program (BEBIS, Ebispro for Windows, Germany). ${ }^{[12]}$ Subjects'food consumption records were taken once a month for three months.

\section{Anthropometric Measurements}

All anthropometric measurements were evaluated by a standardized investigator dietitian who had been trained on this subject. Subjects' body compositions were measured by the BIA method and using the TANITA BC 532 InnerScan (Tokyo, Japan) model device, with bare feet and without any metal accessories on. Their body weight ( $\mathrm{kg})$, waist circumference $(\mathrm{cm})$, hip circumference $(\mathrm{cm})$, neck circumference $(\mathrm{cm})$, midupper arm circumference $(\mathrm{cm})$, and body composition analysis [body fat (\%), body water (\%), and body muscle (\%)] were evaluated at the beginning and end of the study. In addition to these, their waist/height ratio and body mass index (BMl; $\mathrm{kg} / \mathrm{m}^{2}$ ) were analyzed at the beginning and in the third month.

\section{Statistical Analysis}

IBM SPSS Statistics 22.0 (IBM Corp, Armonk, New York, USA) statistical package program was used for statistical analysis. Descriptive statistics for both groups were presented as unit number (n), percentage (\%), mean \pm standard deviation with Pearson chi-square test, and independent samples t-test. The normal distribution of the numerical variable data was evaluated via the Shapiro Wilk normality test and Q-Q graphs. The baseline and third-month measurements were compared by ANOVA, if repetitive. In all comparisons, the value of $p<0.05$ was considered statistically significant.

\section{RESULTS}

Table 1 shows the variables of the subjects' demographic characteristics and dietary habits. The mean age is $33.81 \pm 9.77$ years in $\mathrm{SG}$ and $32.52 \pm 11.89$ years in CG. The mean age of the women in both groups is similar $(p=0.68)$. Average MET values are $4572.00 \pm 1680.18$ in SG and $4399.30 \pm 1716.13$ in CG, and the physical activity levels are sufficient and similar in both groups ( $p>0.05$ ). $92.4 \%$ of SG and $95.7 \%$ of CG have a high school diploma or above, and subjects in both groups have a similar educational background. $42.3 \%$ of SG and $56.5 \%$ of CG work in the private sector, and the professional distributions in both groups are similar ( $>0.05)$. Diagnosed disease rate is $23.1 \%$ in SG and $34.8 \%$ in CG. Endocrine diseases are the most commonly diagnosed diseases in these groups $(83.3 \%$ and $62.5 \%$, respectively). $34.6 \%$ of the subjects in SG and $39.1 \%$ of 
the subjects in CG skip meals, and the most frequently skipped meals are lunch (55.6\%) and dinner (44.4\%), respectively. In both groups, subjects stated that they skipped meals as they were not in the habit of having lunch $(42.9 \%$ and $43.8 \%$, respectively). $30.8 \%$ of SG consumes $1000-1500 \mathrm{~mL}$, and $34.8 \%$ of CG consumes $2000 \mathrm{~mL}$ (and above) of water. The use of vitamin-mineral supplements in CG (43.9\%) is higher than in SG (3.8\%) $(p=0.003)$ (Table 1).

Table 2 shows the comparison of macro and micronutrient intakes of subjects in SG and CG at the beginning and the end of the third month. Baseline and third-month results showed that energy intake and energy from carbohydrates decreased in both groups, and there was no significant difference between $(p>0.05)$. Energy from protein and calcium intake increased in both groups compared to the baseline, and the increase was higher in the group following a diet $(p=0.014$ and $p=0.017$, respectively). Compared to the baseline, energy from fat decreased in SG and increased in $C G$, and fiber intake increased in SG and decreased in CG. However, this difference is not statistically significant ( $p>0.05)$. Vitamin C, vitamin B12, zinc, and iron, which are micronutrient elements, increased in SG and decreased in CG. The difference between groups is not statistically significant ( $p>0.05$ ) (Table 2).

\begin{tabular}{|c|c|c|c|c|}
\hline Variable & Study group $(n=26)$ & Control group $(n=23)$ & Total $(n=49)$ & $\mathbf{p}$ \\
\hline Age (year) $(X \pm S D)$ & $33.81 \pm 9.77$ & $32.52 \pm 11.89$ & $33.20 \pm 10.61$ & 0.68 \\
\hline $\mathrm{MET}(\mathrm{min} /$ week $)(\mathrm{X} \pm \mathrm{SD})$ & $4572.00 \pm 1680.18$ & $4399.30 \pm 1716.13$ & $4451.52 \pm 1687.52$ & 0.72 \\
\hline \multicolumn{5}{|l|}{ Marital Status } \\
\hline $\begin{array}{l}\text { Married } \\
\text { Not married }\end{array}$ & $\begin{array}{l}13(50.0 \%) \\
13(50.0 \%)\end{array}$ & $\begin{array}{l}6(26.1 \%) \\
17(73.9 \%)\end{array}$ & $\begin{array}{l}19(38.8 \%) \\
30(61.2 \%)\end{array}$ & 0.16 \\
\hline $\begin{array}{l}\text { Literate } \\
\text { Secondary school } \\
\text { High school } \\
\text { Bachelor degree } \\
\text { Graduate degree }\end{array}$ & $\begin{array}{c}1(3.8 \%) \\
1(3.8 \%) \\
8(30.8 \%) \\
12(46.2 \%) \\
4(15.4 \%)\end{array}$ & $\begin{array}{c}1(4.3 \%) \\
0(0.0 \%) \\
8(34.8 \%) \\
10(43.5 \%) \\
4(17.4 \%)\end{array}$ & $\begin{array}{c}2(4.1 \%) \\
1(2.0 \%) \\
16(32.7 \%) \\
22(44.9 \%) \\
8(16.3 \%)\end{array}$ & 0.86 \\
\hline \multicolumn{5}{|l|}{ Profession } \\
\hline $\begin{array}{l}\text { Not working } \\
\text { Student } \\
\text { Officer } \\
\text { Housewife } \\
\text { Retired } \\
\text { Self-employment } \\
\text { Private sector }\end{array}$ & $\begin{array}{c}1(3.8 \%) \\
6(23.1 \%) \\
3(11.5 \%) \\
1(3.8 \%) \\
2(7.7 \%) \\
2(7.7 \%) \\
11(42.3 \%)\end{array}$ & $\begin{array}{c}2(8.7 \%) \\
5(21.7 \%) \\
2(8.7 \%) \\
0(0.0 \%) \\
1(4.3 \%) \\
0(0.0 \%) \\
13(56.5 \%)\end{array}$ & $\begin{array}{c}3(6.2 \%) \\
11(22.4 \%) \\
5(10.2 \%) \\
1(2.0 \%) \\
3(6.2 \%) \\
2(4.1 \%) \\
24(48.9 \%)\end{array}$ & 0.86 \\
\hline \multicolumn{5}{|l|}{ Disease diagnosed by a physician } \\
\hline $\begin{array}{l}\text { Yes } \\
\text { No }\end{array}$ & $\begin{array}{c}6(23.1 \%) \\
20(76.9 \%)\end{array}$ & $\begin{array}{c}8(34.8 \%) \\
15(65.2 \%)\end{array}$ & $\begin{array}{l}14(28.6 \%) \\
35(71.4 \%)\end{array}$ & 0.55 \\
\hline \multicolumn{5}{|l|}{ Diseases } \\
\hline $\begin{array}{l}\text { Endocrine diseases } \\
\text { Other diseases }\end{array}$ & $\begin{array}{l}5(83.3 \%) \\
1(16.7 \%)\end{array}$ & $\begin{array}{l}5(62.5 \%) \\
3(37.5 \%)\end{array}$ & $\begin{array}{c}10(71.4 \%) \\
4(28.6 \%)\end{array}$ & 0.58 \\
\hline \multicolumn{5}{|l|}{ Skipping meal } \\
\hline $\begin{array}{l}\text { Yes } \\
\text { No }\end{array}$ & $\begin{array}{c}9(34.6 \%) \\
17(65.4 \%)\end{array}$ & $\begin{array}{c}9(39.1 \%) \\
14(60.9 \%)\end{array}$ & $\begin{array}{l}18(36.7 \%) \\
31(63.3 \%)\end{array}$ & 0.98 \\
\hline \multicolumn{5}{|l|}{ Skipped meal } \\
\hline $\begin{array}{l}\text { Breakfast } \\
\text { Lunch } \\
\text { Dinner }\end{array}$ & $\begin{array}{c}4(44.4 \%) \\
5(55.6 \%) \\
0(0.0 \%)\end{array}$ & $\begin{array}{l}2(22.2 \%) \\
3(33.3 \%) \\
4(44.5 \%)\end{array}$ & $\begin{array}{l}6(31.6 \%) \\
9(47.4 \%) \\
4(21.0 \%)\end{array}$ & 0.06 \\
\hline \multicolumn{5}{|l|}{ Reason for skipping meal** } \\
\hline \multicolumn{5}{|l|}{ Water consumption (mL) } \\
\hline $\begin{array}{l}0-500 \\
500-1000 \\
1000-1500 \\
1500-1999 \\
\geq 2000 \mathrm{~mL}\end{array}$ & $\begin{array}{l}4(15.4 \%) \\
6(23.1 \%) \\
8(30.8 \%) \\
5(19.2 \%) \\
3(11.5 \%)\end{array}$ & $\begin{array}{l}2(8.7 \%) \\
4(17.4 \%) \\
4(17.4 \%) \\
5(21.7 \%) \\
8(34.8 \%)\end{array}$ & $\begin{array}{l}6(12.3 \%) \\
10(20.4 \%) \\
12(24.5 \%) \\
10(20.4 \%) \\
11(22.4 \%)\end{array}$ & 0.08 \\
\hline \multicolumn{5}{|c|}{ Using vitamin-mineral supplements } \\
\hline $\begin{array}{l}\text { Yes } \\
\text { No }\end{array}$ & $\begin{array}{c}1(3.8 \%) \\
25(96.2 \%)\end{array}$ & $\begin{array}{l}10(43.5 \%) \\
13(56.5 \%)\end{array}$ & $\begin{array}{l}11(22.4 \%) \\
38(77.6 \%)\end{array}$ & $0.00^{*}$ \\
\hline
\end{tabular}




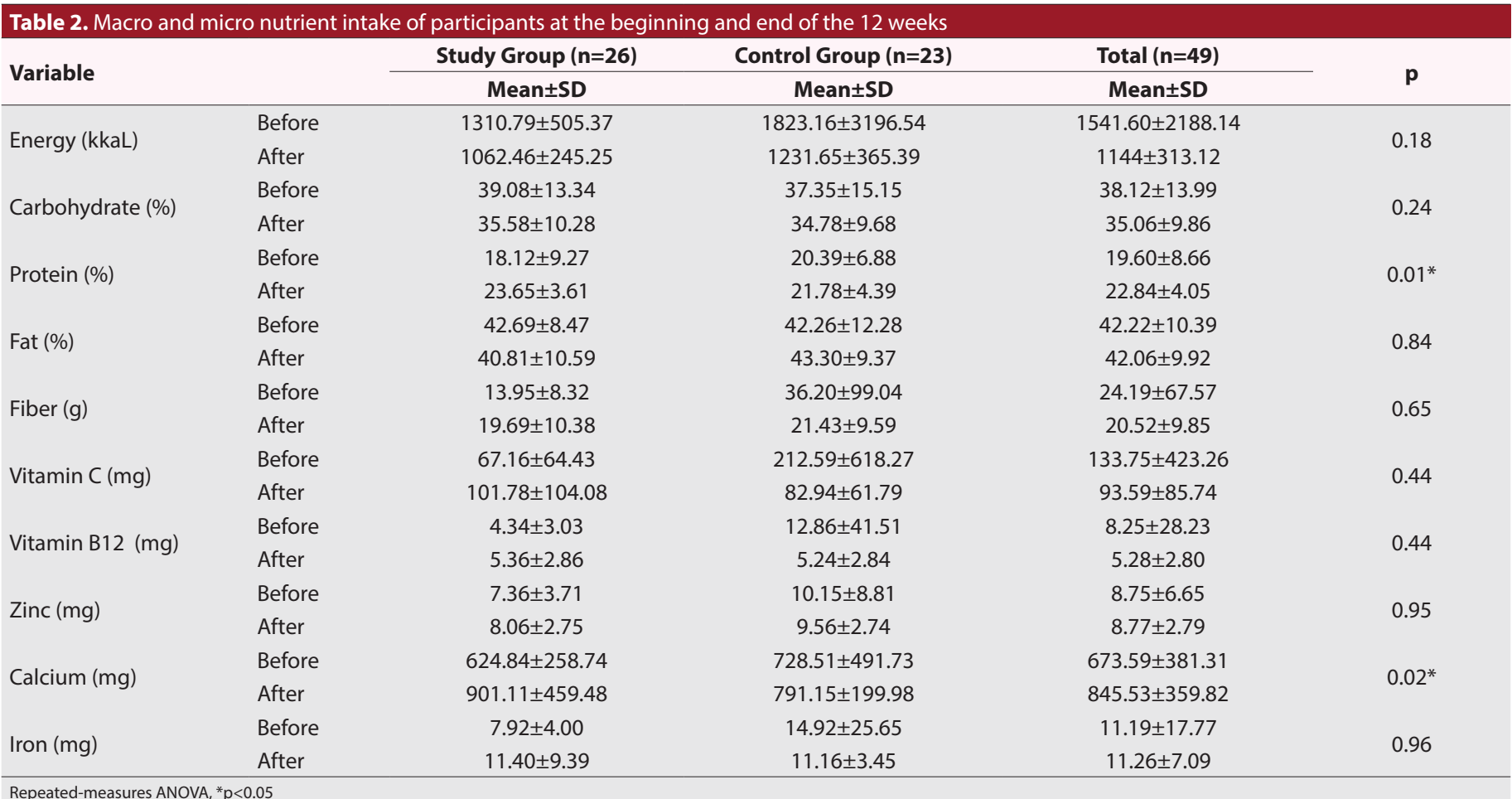

Table 3 shows the comparison of the anthropometric measurements of the subjects at the beginning and in the third month. Compared to CG, SG had a higher decrease in body weight, BMI, waist circumference, hip circumference, waist/ height ratio, and a higher increase in basal metabolic rate (BMR), body muscle ratio, and body water ratio $(p<0.05)$. Reduction in neck circumference was more dramatic in the control group $(p=0.01)$. Upper middle arm circumference decreased in SG and increased in CG; however, the difference between the two groups was not significant ( $p>0.05$ ) (Table 3).

Table 3. Anthropometric measurements of participants at the beginning and end of the 12 weeks

\begin{tabular}{|c|c|c|c|c|c|}
\hline \multirow{2}{*}{ Variable } & & Study Group ( $n=26$ ) & Control Group $(n=23)$ & Total $(n=49)$ & \multirow{2}{*}{$\mathbf{p}$} \\
\hline & & Mean \pm SD & Mean \pm SD & Mean \pm SD & \\
\hline \multirow{2}{*}{ Body weight (kg) } & Before & $67.10 \pm 10.94$ & $61.68 \pm 10.63$ & $64.59 \pm 10.92$ & \multirow{2}{*}{$0.00^{*}$} \\
\hline & After & $63.63 \pm 9.63$ & $60.65 \pm 10.20$ & $62.24 \pm 9.81$ & \\
\hline BMI $\left(\mathrm{kg} / \mathrm{m}^{2}\right)$ & After & $23.28 \pm 3.12$ & $22.23 \pm 3.59$ & $22.75 \pm 3.33$ & $0.00^{*}$ \\
\hline \multirow{2}{*}{ WC (cm) } & Before & $78.12 \pm 13.27$ & $73.07 \pm 9.32$ & $87.18 \pm 70.72$ & \multirow{2}{*}{$0.00^{*}$} \\
\hline & After & $71.77 \pm 10.89$ & $69.48 \pm 9.25$ & $70.72 \pm 10.01$ & \\
\hline $\mathrm{HC}(\mathrm{cm})$ & After & $98.15 \pm 9.26$ & $95.43 \pm 7.54$ & $96.96 \pm 8.45$ & $0.00^{*}$ \\
\hline \multirow{2}{*}{$\mathrm{NC}(\mathrm{cm})$} & Before & $32.50 \pm 1.86$ & $32.30 \pm 2.24$ & $32.42 \pm 2.01$ & \multirow{2}{*}{$0.01 *$} \\
\hline & After & $32.31 \pm 1.64$ & $32.00 \pm 2.13$ & $32.16 \pm 1.86$ & \\
\hline \multirow{2}{*}{ WC/Height } & Before & $0.47 \pm 0.08$ & $0.44 \pm 0.06$ & $0.45 \pm 0.07$ & \multirow{2}{*}{$0.00^{*}$} \\
\hline & After & $0.43 \pm 0.07$ & $0.42 \pm 0.06$ & $0.42 \pm 0.06$ & \\
\hline MUAC (cm) & Before & $27.42 \pm 6.10$ & $25.35 \pm 6.66$ & $26.48 \pm 6.33$ & 0.75 \\
\hline \multirow{2}{*}{ Body water (\%) } & Before & $48.44 \pm 2.96$ & $50.58 \pm 4.79$ & $49.38 \pm 4.02$ & \multirow{2}{*}{$0.00^{*}$} \\
\hline & After & $50.66 \pm 3.00$ & $51.09 \pm 4.79$ & $51.05 \pm 3.89$ & \\
\hline \multirow{2}{*}{ FFM (\%) } & Before & $43.40 \pm 4.05$ & $40.81 \pm 3.23$ & $42.17 \pm 3.83$ & \multirow{2}{*}{0.98} \\
\hline & After & $43.23 \pm 4.10$ & $40.96 \pm 4.02$ & $42.22 \pm 4.16$ & \\
\hline \multirow{2}{*}{ BMR (kkaL) } & Before & $1378.77 \pm 130.45$ & $1341.30 \pm 105.37$ & $1365.44 \pm 119.24$ & \multirow{2}{*}{$0.00^{*}$} \\
\hline & After & $1426.50 \pm 137.80$ & $1368.39 \pm 126.70$ & $1399.80 \pm 125.43$ & \\
\hline
\end{tabular}




\section{DISCUSSION}

Body composition refers to the different tissues that make up the total body mass, usually expressed in muscle, fat, bone, and residual mass. Age, gender, muscle structure, physical activity level, diseases, and nutrition can affect body composition. ${ }^{[10]}$ Diet is affected by the dietary habits of a society and its social, economic, and cultural conditions. ${ }^{[13]}$

Many studies report a positive correlation between physical activity level and educational background. ${ }^{[14,15]} \mathrm{A}$ higher level of education may help individuals see the benefits of physical activity and engage in such activities, especially in their spare time. ${ }^{[16]} \mathrm{A}$ meta-analysis on this subject suggests that doing physical activities in one's spare time is not associated with educational background. ${ }^{[17]} 53.3 \%$ of the subjects in Basoglu et al.'s study (2018) on exercise dependence and $41.6 \%$ in de Souza Ferraz et al.'s (2020) study had bachelor's degrees. ${ }^{[18,19]}$ The subjects in this study have a high level of education (65.3\% of them have bachelor's degrees or above), which is a critical factor in their physical activity levels.

The World Health Organization's Guidelines on Physical Activity and Sedentary Behavior Guide (2020) recommend that adults perform 150-300 minutes of medium intensity or 75-150 minutes of high intensity or a combination of medium and high intensity aerobic physical activities on a weekly basis. Regular exercises promoting muscular endurance are recommended for all age groups. ${ }^{[20]}$ Data from the Turkey Nutrition and Health Survey 2019 show that $37.6 \%$ of individuals aged 19 and over do not follow this recommendation. ${ }^{[2]}$ Physical inactivity, which is one of the common risk factors of chronic diseases, ranks fourth in the worldwide risk factors leading to death and is responsible for $15 \%$ of all-cause deaths in Turkey. ${ }^{[20,21]}$ Following a healthy diet and increasing your physical activity level are among the key recommendations that should be taken to age healthily and minimize old age-related health risks. Regular physical activity together with a healthy diet plays a critical role in preventing chronic diseases. ${ }^{[20]}$ In this study, only a small group of subjects (28.6\%) were diagnosed by a physician, which maybe thanks to the fact they had exercising habits, and most of them had endocrine diseases (71.4\%).

Dietary habits play a critical role in the physical and mental health of individuals. An insufficient number of meals, inconvenient meal times, and skipping meals are among the factors that negatively affect an adequate and balanced diet. The frequency of food consumption and the amount and ratio of energy and nutrients per meal is essential in maintaining the body's physiological balance and protecting the organs. [22] Peker and Yağmur's study (2018) showed that subjects regularly had dinner and skipped lunch most frequently. ${ }^{[23]}$ Following the literature, this study suggested that subjects skipped meals, which may negatively affect their adequate and balanced diet and exercise program.

Water, defined as the essential element of life, assumes a vital role in maintaining cellular homeostasis. Analyzing water consumption is critical in studies conducted on diet. Australian Nutrition and Physical Activity Study 2011-2012 results show that water consumption decreases with aging in adults. ${ }^{[24]}$ Turkey Dietary Guidelines 2015 recommends that adults consume 2-2.5 liters of fluid a day, and the fluid consumed should be water in particular. ${ }^{[25]} A$ study conducted on adolescents found that $39.9 \%$ of the subjects drank 6-10 glasses of water a day. ${ }^{[2]}$ Our study suggested that $24.5 \%$ of the subjects drank 1000-1500 mL of water at the beginning. Considering that physical activity increases fluid loss in the body, it is critical to take an adequate amount of fluid when exercising.

Nutritional supplements containing vitamins and minerals are widely used today. However, under the principles of an adequate and balanced diet, it is recommended that they taken within a diet. It is reported that few nutritional supplements boost performance, and they generally cause health problems. ${ }^{[27]}$ A study conducted on 723 people in Brazil showed that $64.7 \%$ of the subjects who attended the gym used vitamin-mineral supplements. ${ }^{[28]}$ In the study conducted on bodybuilding men, $64.0 \%$ of the subjects used nutritional supplements. ${ }^{[27]}$ In this study, unlike the literature, $77.6 \%$ of the subjects did not use vitamin-mineral supplements. It is good news that the vast majority of the subjects do not use such supplements to increase exercise performance.

It is known that personalized healthy diet programs have positive effects on body weight and body fat loss. ${ }^{[8]}$ Turkey Dietary Guidelines 2015 recommends that women aged 18-64 should consume energy from carbohydrates by 45$60 \%$, protein by $10-20 \%$, and fat by $20-35 \% .{ }^{[25]}$ It was found that the average energy, protein, carbohydrate, mono and polyunsaturated fatty acids, fiber, and sodium intakes of women who exercised in the postmenopausal period were significantly lower than the dietary reference intake (DRI) value. ${ }^{[29]} A$ similar study found that the energy and fat intakes of women were above the DRI while their protein and calcium intakes were below the DRI. ${ }^{[30]}$ In our study, neither group could meet the recommendations specified in the guidelines. At the beginning and the end of the study, the energy from carbohydrates was low and energy from fat was high. At the beginning, energy from protein (19.6\%) complied with the recommendations in Turkey Dietary Guidelines. At the end, however, it was above (22.8\%) what was recommended. It suggests that subjects increase their protein intake to promote muscle gain with exercise. Also, the protein intake of women who were on a weight-loss diet was higher than those who were not. Factors such as the inability to comply with the dietician's recommendations and consuming more protein thinking that it increases the metabolic rate may have led the women on a weight-loss diet into increasing their protein intake. Similarly, a study involving exercise and dietary interventions applied to overweight and obese women found that energy and fat intake decreased and protein and carbohydrate intake increased. ${ }^{[31]}$ 
A study conducted on people who exercised found that their calcium intake was above the DRI value, while another showed that it was below the DRI. ${ }^{[29,30]}$ It was found that the calcium intake was higher in the study group than in the other. The recommendation to consume more dairy products, thought to be effective for maintaining electrolyte balance before or after exercise, improving exercise performance, and reducing body weight, may have been effective in this case.

It is suggested that regular physical activity has positive effects on body composition, depending on the type of exercise. ${ }^{[1,3]}$ This study showed that the study group had a higher decrease in body weight, BMI, waist circumference, hip circumference, and waist/height ratio and a higher increase in $\mathrm{BMR}$, muscle, and water ratio than the control group. A similar study found a significant difference in body weight, BMI, waist circumference, lean body mass, and BMR after 8 weeks of pilates compared to the baseline values. ${ }^{[32]}$ In contrast to this study, no significant improvement in fat and muscle mass was observed in another study. ${ }^{[33]}$

Our study has several strengths and weaknesses. Its primary limitation is that no content was defined for the weightloss diet and/or it was designed in a randomized controlled manner, thus preventing dietary treatment from being standardized. Only women of childbearing age were included in the study. The subjects do not represent all age groups and sexes, making it difficult for us to refer to the general population. Food consumption records of the subjects were taken once every month with the 24-hour recall method, which does not indicate their overall nutritional status. Future studies should include a three-day food consumption record for each month and monitor compliance with personalized diet programs.

Studies on the effect of pilates alone or in combination with a weight-loss diet on dietary habits and anthropometric measurements are inadequate. This is one of the strengths of our study. Maximum care was taken and ethical rules were in place. The statistical data obtained made a significant contribution to the literature. New studies should be conducted to comprehensively evaluate the data obtained within the scope of this study.

\section{CONCLUSION}

Following a weight-loss diet and doing reformer pilates led to positive changes in subjects' body composition compared to reformer pilates alone and increased dietary protein and calcium intake. Our results support that a combination of diet and reformer pilates may be more effective in women doing reformer pilates than exercise alone. Randomized controlled studies are needed to evaluate the effect of nutritional intervention on people doing pilates of different ages, sex, and disease status.

\section{ETHICAL DECLARATIONS}

Ethics Committee Approval: The study was carried out with the permission of İzmir Kâtip Çelebi University Noninterventional Clinical Research Ethics Committee (Date: 13.02.2020, Decision No: 629).

Informed Consent: All women signed the free and informed consent form.

Referee Evaluation Process: Externally peer-reviewed.

Conflict of Interest Statement: The authors have no conflicts of interest to declare.

Financial Disclosure: The authors declared that this study has received no financial support.

Author Contributions: All of the authors declare that they have all participated in the design, execution, and analysis of the paper, and that they have approved the final version.

Note: This study was presented as an oral presentation at the congress of the 3rd International Congress on Agriculture, Environment and Health in Aydın, 12-14 November 2020.

\section{REFERENCES}

1. Aladro-Gonzalvo AR, Machado-Díaz M, Moncada-Jiménez J, HernándezElizondo J, Araya-Vargas G. The effect of pilates exercises on body composition: a systematic review. J Bodyw Mov Ther. 2012;16(1):109-14.

2. Şavkin R, Aslan UB. The effect of pilates exercise on body composition in sedentary overweight and obese women. J Sports Med Phys Fitness. 2017;57(11):1464-70.

3. Rayes $A B R$, de Lira CAB, Viana RB, et al. The effects of pilates vs. aerobic training on cardiorespiratory fitness, isokinetic muscular strength, body composition, and functional tasks outcomes for individuals who are overweight/obese: a clinical trial. PeerJ 2019;7:e6022.

4. Roller M, Kachingwe A, Beling J, Ickes DM, Cabot A, Shrier G. Pilates reformer exercises for fall risk reduction in older adults: $A$ randomized controlled trial. J Bodyw Mov Ther 2018;22(4):983-98.

5. Aka H, İbiş S, Arıcı R. Kadınlara uygulanan 8 haftalık reformer pilates egzersizlerinin vücut kompozisyonuna ve bazı fiziksel uygunluk parametrelerine etkisi. GUSBD. 2020;5(4):573-89.

6. Pekel HA, Aydos L, Uzun A, Bozoğlu MS, Demirel M. The effect of zumba and reformer exercises on female body composition. IJOEEC. 2020;5(11):2316-39.

7. Kaya M, Paktaş $Y$, Topçu İ, Karabacak E. Pilates reformer egzersizlerinin sedanter kadınlarda vücut ağırlığı, kas çevresi ve esneklik düzeylerine etkilerinin incelenmesi. Sivas Cumhuriyet Univ Sports Sci J. 2020; 1(3):1309.

8. Vassilopoulou E, Piperari G, Christoforou C. Is Zumba ${ }^{\circledR}$ fitness effective to manage overweight without dietary intervention?. AJNE. 2016;1(3):11321.

9. Aragon AA, Schoenfeld BJ, Wildman R, et al. International society of sports nutrition position stand: diets and body composition. J Int Soc Sports Nutr. 2017;14(1):16.

10. Fourie M, Gildenhuys GM, Shaw I, Shaw BS, Toriola AL, Goon DT. Effects of a mat pilates programme on body composition in elderly women. West Indian Med J. 2013;62(6):524-8.

11. IPAQ-SF Research Committee. Guidelines for data processing and analysis of the International Physical Activity Questionnaire (IPAQ-SF)-short and long forms. 2005 [cited 2021 Mar 15] Available from: http://www. IPAQ-SF. ki. se/scoring. pdf.

12. BEBiS Programı, B. B. S. P. Ebispro for Windows, Stutgart, Germany; Turkish version BEBIS; Data Bases: Bundeslebenmittelschlüssell, 11.3 and other sorces.18 
13. Schoufour JD, de Jonge EA, Kiefte-de Jong JC, et al. Socio-economic indicators and diet quality in an older population. Maturitas. 2018;107:717.

14. Macías R, Garrido-Muñoz M, Tejero-González CM, Lucia A, López-Adán E, Rodríguez-Romo G. Prevalence of leisure-time sedentary behaviour and sociodemographic correlates: a cross-sectional study in Spanish adults. BMC Public Health. 2014;14(1):972.

15. Farrell L, Hollingsworth B, Propper C, Shields MA. The socioeconomics gradient in physical inactivity: Evidence from one million adults in England. Soc Sci Med. 2014;123:55-63.

16. Del Duca GF, Nahas MV, Garcia LMT, Mota J, Hallal PC, Peres MA. Prevalence and sociodemographic correlates of all domains of physical activity in Brazilian adults. Prev Med Rep. 2013;56(2):99-102.

17. Beenackers MA, Kamphuis CB, Giskes K, et al. Socioeconomic inequalities in occupational, leisure-time, and transport related physical activity among European adults: a systematic review. Int J Behav Nutr Phys Act. 2012;9(1):1-23.

18. Basoglu UD. Exercise Addiction: A Comparison between the Individuals Who Exercise for Physical Recreation and Who Receive Personal Exercise Training. J Educ Train Stud 2018;6(12):21-5.

19. de Souza Ferraz V, Cruz ADFC, Ferreira MAM, et al. Efeito do Método Pilates sobre a Função Sexual, a Força da Musculatura do Assoalho Pélvico e a Qualidade de Vida em Mulheres Sobreviventes do Câncer de Mama. Revista Brasileira de Cancerologia. 2020;66(2).

20. Bull FC, Al-Ansari SS, Biddle S, et al. World Health Organization 2020 guidelines on physical activity and sedentary behaviour. Br J Sports Med. 2020;54(24):1451-62.

21. T.C. Sağlık Bakanlığı. Türkiye beslenme ve sağlık araştırması 2019. T.C. Sağlık Bakanlığı Halk Sağlığı Genel Müdürlüğü, Publication Number: 1132, Ankara, 2019 [cited 2021 Apr 9]; Available from: https://hsgm.saglik.gov. tr/depo/birimler/saglikli-beslenme-hareketli-hayat-db/Yayinlar/kitaplar/ TBSA_RAPOR_KITAP_20.08.pdf

22. Paoli A, Tinsley G, Bianco A, Moro T. The influence of meal frequency and timing on health in humans: the role of fasting. Nutrients. 2019;11(4):719.

23. Peker A, Yağmur C. Yetişkin şişman kadınlarda zayıflama diyeti ve egzersiz uygulamasının vücut ağıllık kaybı ile vücut bileşimi ve antropometrik ölçümler üzerine etkisi. Ç.ü. Müh. Mim. Fak. Dergisi. 2018; 35(6):81-90.

24. Zhixian JM, Zhang M, Sui Z, Rangan AM. Water consumption among Australian population: Results from 2011-12 National Nutrition and Physical Activity Survey. Obes Res Clin Pract. 2019;13(1):112-3.

25. T.C. Sağlık Bakanlığı. Türkiye beslenme rehberi 2015 (TÜBER). T.C. Sağlık Bakanlığı Halk Sağlığı Müdürlüğü Publication Number: 1031, Ankara, 2016.

26. Nişancı Kılınç F, Çakır B, Durmaz SE. Spor yapan adölesanlar optimal düzeyde besleniyor mu? Obezite durumları ve Akdeniz Diyeti'ne uyum düzeyleri. Turkiye Klinikleri J Sports Sci. 2020;12(1):49-57.

27. Özdoğan $Y$, Karataş E, Uçar A. Vücut geliştirme sporu yapan erkeklerin beslenme alışkanlıkları ve ergojenik besin destekleri kullanma durumları. AUHSJ. 2018;9(4):378-84.

28. Lacerda FMM, Carvalho WRG, Hortegal EV, Cabral NAL, Veloso HJF. Factors associated with dietary supplement use by people who exercise at gyms. Rev Saude Publica. 2015;49:63.

29. Ranasinghe C, Shettigar PG, Garg M. Dietary intake, physical activity and body mass index among postmenopausal women. J Midlife Health. 2017;8(4):163.

30. Kashyap A, Chhabra P. Assessment of nutritional intake and nutritional knowledge of rural post-menopausal women. IJSHR. 2019; 4(3):68-73.

31. Castro EA, Carraça EV, Cupeiro R, et al. The effects of the type of exercise and physical activity on eating behavior and body composition in overweight and obese subjects. Nutrients. 2020;12(2):557.

32. Cakmakçi O. The effect of 8 week plates exercise on body composition in obese women. Coll Antropol. 2011; 35(4):1045-50.

33. Aibar-Almazán A, Martínez-Amat A, Cruz-Díaz D, et al. The influence of pilates exercises on body composition, muscle strength, and gait speed in community-dwelling older women: A randomized controlled trial. J Strength Cond Res 2020;10.1519/JSC.0000000000003790. 